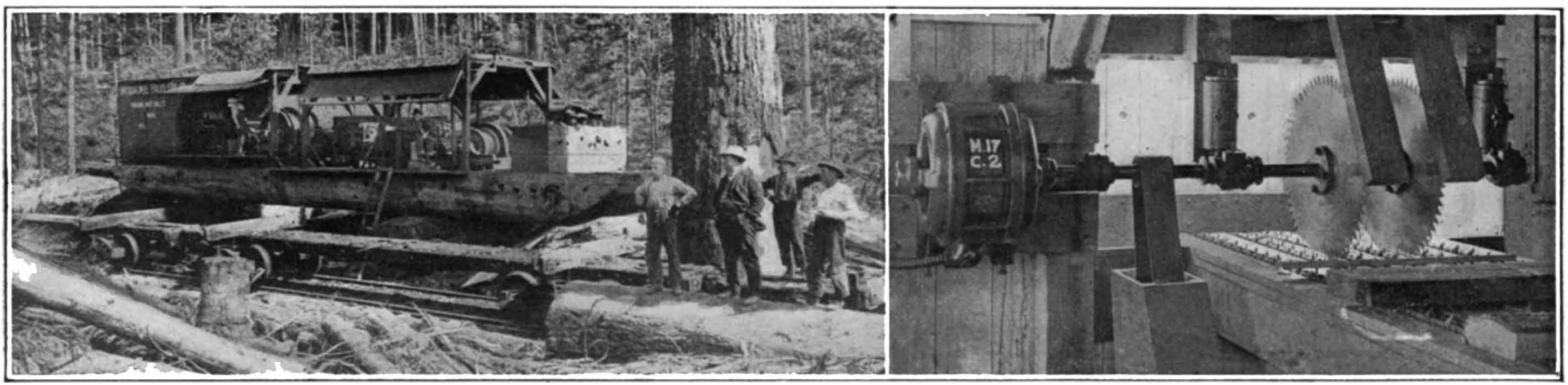

Left: Electric yarder and duplex loader mounted on sled. Right: Induction motor for direct drive of wood saws

Flectrically-operated equipment of the logging industry

\section{Logging by Electricity}

By Alf red Longville

VERCOMING seemingly ins'irmountable obstacles, a logging company operating in the States of Washington and Oregon has demonstrated the value of electricity in felling timber. For the first time, perhaps, in the history of the industry electric current has supplanted steam power for exploiting lumber resources su a region steam power for exploiting lumber resources was constructed, penetrating the densely wooded areas of the National forests, and rendering available for market $14,000,000$ feet of timber.

Electrifying the woods was a "trail-blazing" feat of difficult attainment. A steam donkey or locomotive, minus the steam, was the nucleus for initial experiments. Without steam, the first obstacle encountered was the absence of a signal whistle. As a makeshift arrangement, an electric horn was attached, located 50 feet from the electrical equipment; but the din of machinery operation rendered indistinct the clarion call of the whistle in giving signals to the working crew.

Here is how the problem was solved: A $2 \frac{1}{2}$ by 3 air compressor was installed, hooked up to a 3-horsepower motor. The compressor is piped to a storage tank, 30 by 60 inches, and the pressure is constant at 100 pounds. Driving the air by the operation of the motor, about five minuies each hour, the pressure is the motor, about five minuies each hour,

Logging by electricity was begun with a 250 kva. transformer, subsequent developments proving the inadequateness of this capacity. Tests, however, have not offered definite recommendations on this point. The transformer, at donkey end of transmission line, is placed three or four hundred feet from the spar tree obviating interference of yarding and loading.

The 13,000-volt transmission is terminated on two poles at 8 foot centers, at the transformer. A disconnect switch is mounted on these poles, making it feasible to cut off the current at this juncture. Current from the 550-volt side of the transformer is conveyed to the motor through a 3-conductor armored submarine cable placed along the ground between the transformers and yarder motor.

Difficulties of operating the motor slowly enough to be in unison with the requirements of logging and in regulation of drum controller in starting, stopping and controlling speed of the motor had to be surmounted. Acting upon the theory that it is essential to add re sistance in rotor circuit until the motor speed is lessened sufficiently, the electricians then rearranged the wiring of the drum controller for the accommodation of a wider range of control. Barrels of water were connected with each of the three phases of the rotor nected with each of the three phases of the rotor
circuit until the speed required was ascertained by raising or lowering the barrel of water to the circuit. Imagine the exasperation of the lumberman hauling around barrels of water as excess luggage to an equipment already cumbersome! But the tests of connecting the donkey engine with the water harrel is not a frethe donkey engine with the water har quent performance. Basic information is available from a single experiment: Simply calculate the watts necessary to be obtained in some other form of resistor. The Washington logging company added a resistance of $3 \mathrm{ohms}$ in each of two phases and a resistance of $6 \mathrm{ohms}$ in the remaining phase of the rotor circuit.

A cost accounting system has been kept to indicate the expenditures as well as the merits of the system of logging by electricity. For building and maintaining the transmission line, calculations have been based on 5 per cent depreciation for the copper and conductor, 20 per cent depreciation for cross arms and insulators, and 100 per cent for labor and incidentals. A half a day is required for four men to establish the transformer erery time the yarder is moved to a new setting. The yarder has been in operation for 234 consecutive days warder has been in operation for

Comparative costs of logging with electricity and steam, as evidenced by the records of this Western lumber company, produce the following fact: Electric ally-driven yarder $\operatorname{logs}$ for 52 cents per thousand lesssáving $\$ 7,280$ in 210 days on a yarder alone. Supplement the cost of maintaining motor and controller, and the total cost is only 11 cents per thousand feet of tim ber. It requires 2.8 kilowatt hours energy input to $\log$ 1,000 feet.

Aside from the possibilities of developing power sufficient to do logging in heavy timber, at a reasonable outlay of expenditures, the United States Forest Service considers the introduction of electrical equipment as an added precaution in minimizing the annual toll of $\$ 40,000,000$ exacted by forest fires. Logging equipment and camps are the sources of unnumbered forest conflagrations.

The electric yarder and duplex loader in operation form the subject of our present colored cover.

\section{The Civil War Carved in Granite By James Anderson}

STONE MOUNTAIN, a solid granite monolith rising $S$ sheer out of the landscape about twelve miles east of Atlanta, Georgia, will begin this spring to assume the aspect of a granite memorial to the Civil War. "The Lost Cause," a gigantic sculptural representation of an army of one thousand Confederate leaders, is to be carved in the face of the mountain, which is fifteen hundred feet long and one thousand feet high. After eight years of planning, the engineering framework for this stupendous monument is being laid, so that in the spring work on the army may be started. Gutzon Borglum, the eminent American sculptor who originated the idea of this vast memorial, is to superintend its execution.

Plans had been completed in 1917 for beginning the work when America entered the World War. The mountain had been surveyed, and a road cut to the top. Even hoist cables and some machinery had been installed. Nothing further was done, however, until January of this year, when complete support was pledged for the renewal and completion of the undertaking after the unavoidable interruption.

The huge nature of the conception staggers the imagination. Big as the mountain is, it is absolutely without seam, crevice, or fissure. The monolith's southern, eastern and western exposures are oval in shape, so that the vast natural canzas is like a tea-cup cut in two. No other stone in the world, so far as known, affords so wonderful an opportunity for the sculptor. Mr. Gutzon Borglum says the quality is perfect, as the gray granite of the northern side, where the army vill take shape, is protected from the sun and is not affected by the weather. 'There is never sufficient frost to react on the stone. The southern exposure is influenced slightly by the action of the sun, but the moisture of the dew creates a slight expansion, so that altogether conditions are ideal for a permanent memorial.

The sculptural aspects of the work presented a task which might have made an artist less experienced than Mr. Borglum shrink from beginning it. The plans have, however, been completed. The army is to be composed, as said, of one thousand complete figures. Each figure will represent some leader in the Army of the South, but more than th (Continued on page 297)

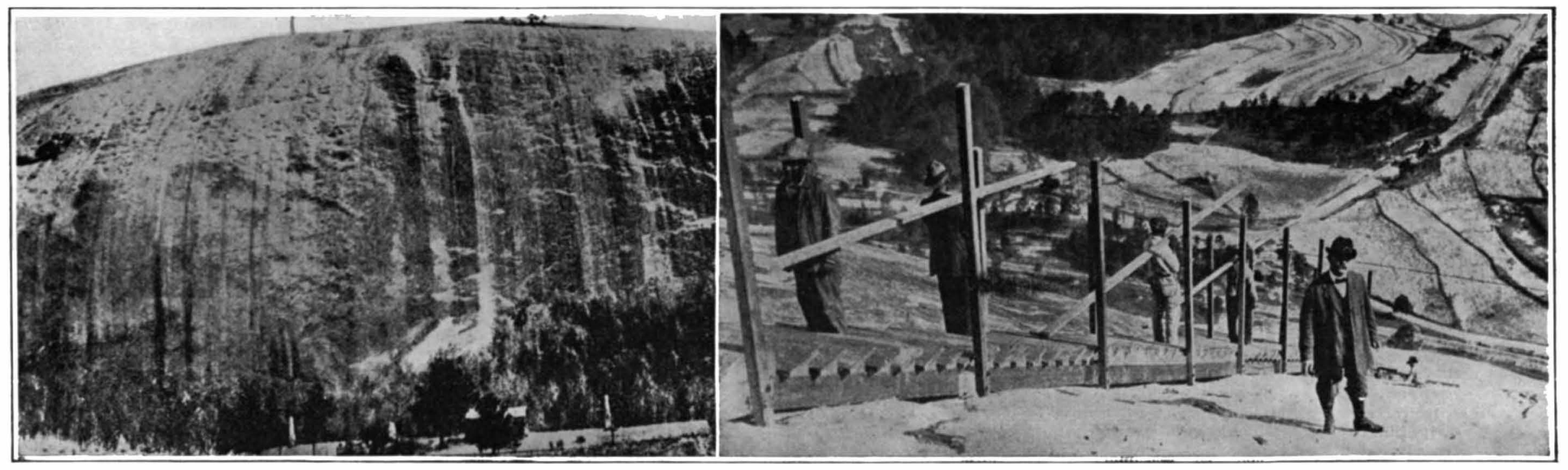

Left: The northern exposure of Stone Mountain, on which the Borglum sculptural representation of the "Lost Cause" will appear. Right: View of the countryside from the top of Stone Mountain

The natural canvas on which the Civil War is to be painted in granite 